\title{
Fragmentations and Reactions of the Organophosphate Insecticide Diazinon and its Oxygen Analog Diazoxon Studied by Electrospray Ionization Ion Trap Mass Spectrometry
}

\author{
J. D. Barr ${ }^{*}$ \\ Department of Chemistry, Southampton University, Southampton, United Kingdom \\ A. J. Bell, M. Bird, J. L. Mundy, J. Murrell, C. M. Timperley, \\ and P. Watts \\ Detection Department, Porton Down, Salisbury, Wiltshire, United Kingdom \\ F. Ferrante \\ Dipartmento di Chimica Fisica F. Accascina, Università degli Studi di Palermo, Palermo, Italy
}

\begin{abstract}
The fragmentations and reactions of Diazinon and related compounds have been studied by electrospray ionization ion trap mass spectrometry. Several novel fragmentation and rearrangements have been observed, including an intramolecular thiono-thiolo rearrangement. The stability, in the gas-phase, of the protomers of 2-isopropyl-4-methyl-6-pyrimidinol has been demonstrated. The complexity of the gas phase ion processes observed suggest that, at present, caution should be exercised in using this approach for the analysis of environmental and other samples until our understanding of these processes increases considerably. (J Am Soc Mass Spectrom 2005, 16, 515-523) @ 2005 American Society for Mass Spectrometry
\end{abstract}

I nvestigations of the fragmentations and reactions of the ions of simple organophosphate esters produced by electrospray ionization (ESI) in an ion trap (IT) mass spectrometer demonstrated that detailed structural information could be obtained by sequential Collision Induced Dissociation (CID) [1-3]. These studies have been extended to more complex organophosphates such as the chemical warfare agents O-ethyl $S$-(2-diisopropylamino)ethyl methylphosphonothiolate (VX) and O-isobutyl $S$-(2-diethylamino)ethyl methylphosphonothiolate (RVX) [4], and organophosphate insecticides, one of which Diazinon I, together with its oxygen analog Diazoxon II, and pyrimidinol side-chain III, are the subject of the present paper (see Figure 1 for structures).

Two ESI-MS studies of protonated Diazinon have been reported $[5,6]$ but tandem quadrupole instruments were used and fragmentation pathways could not be studied as extensively as in the IT mass spectrometer. There are significant differences in the results

Published online February 19, 2005

Address reprint requests to Dr. P. Watts, Detection Department, Proton Down, Salisbury, Wiltshire SP4 0JQ, United Kingdom. E-mail: pwatts. rgs@ukgateway.net

* Current address: Institut Català d'Investigació Química (ICIQ), Av. Paisos Catalans, s/n., 43007 Tarragona, Spain. of these studies and the present one. Initially in this study, a commercial analytical standard of Diazinon was used. The data obtained suggested that either thiono-thiolo isomerization (Figure 2) had occurred in the fragmentation process or in the sample prior to analysis.

Such isomerizations are well known and have been used in synthesis (for a review of relevant papers, see reference 3). A commercial sample of Diazinon was purified and analyzed to investigate which of these two possibilities was correct. In the event, it was found that isomerization had not occurred in the sample. The method of purification of Diazinon, synthesis of Diazoxon, and results of their analyses are described here.

\section{Experimental}

\section{Materials and Analytical Equipment}

Diethyl chlorophosphate and 2-isopropyl-4-methyl6-pyrimidinol were purchased from Aldrich Ltd (Gillingham, UK) and were used as received. Triethylamine was dried by distillation from calcium hydride. Anhydrous solvents were used. Plates for thin layer chromatography (TLC) comprised MK6F silica gel 60A 


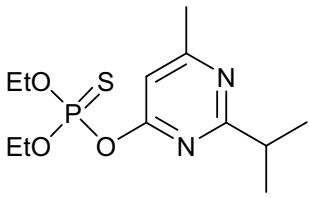

I

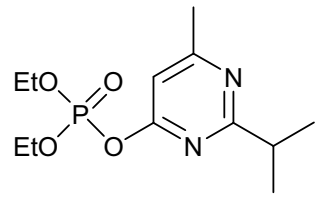

II

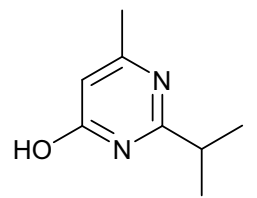

III

Figure 1. Structures of Diazinon I, Diazoxon II, and the side chain pyrimidinol II.

$(2.5 \times 7.5 \mathrm{~cm}$, layer thickness $250 \mu \mathrm{g})$ and were purchased from Whatman International Ltd. (Maidstone, UK). Silica for column chromatography, particle size 40-63 $\mu \mathrm{m}$, was obtained from BDH Laboratory Supplies (Poole, UK). NMR spectra were recorded on a JEOL Lambda 500 instrument (operating at $500 \mathrm{MHz}$ for ${ }^{1} \mathrm{H}, 125 \mathrm{MHz}$ for ${ }^{13} \mathrm{C}$ and $202 \mathrm{M} \mathrm{Hz}$ for ${ }^{31} \mathrm{P}$ spectra) as solutions in $\mathrm{CDCl}_{3}$, with internal reference $\mathrm{SiMe}_{4}$ for ${ }^{1} \mathrm{H}$ and ${ }^{13} \mathrm{C}$, and external $(\mathrm{MeO})_{3} \mathrm{P}(\delta 140 \mathrm{ppm})$ for ${ }^{31} \mathrm{P}$ spectra. Data are listed as follows: chemical shifts in ppm from reference on the $\delta$ scale, integration, multiplicity $(\mathrm{s}=$ singlet, $\mathrm{d}=$ doublet, $\mathrm{t}=$ triplet and sept $=$ septet), coupling constant $(\mathrm{J} / \mathrm{Hz})$ and assignment. IR spectra were recorded as liquid films on a Nicolet SP210 instrument using Omnic software (Thermo Electron Corp., Madison, Wisconsin); s after a frequency indicates that the band was strong. Reaction mixtures were monitored by TLC and components visualized using UV light $(\lambda=254 \mathrm{~nm})$.

\section{O,O-Diethyl O-[2-Isopropyl-4-Methyl-6- Pyrimidinyl] Thiophosphate (Diazinon)}

TLC experiments with commercial Diazinon, a yellow liquid of $90+\%$ purity, were performed using several solvent systems (hexane-acetone, hexane-ethyl acetate, and chloroform), the best separation occurring with 12:1 hexane-acetone. The main spot appeared at $R_{f} 0.2$ and an impurity spot at $R_{\mathrm{f}} 0.1$. Chromatography using a column of silica gel (15 cm long and $5 \mathrm{~cm}$ in diameter) and eluting with 12:1 hexane-acetone gave Diazinon as a colorless liquid (3.6 g) of 99\% purity. ${ }^{1} \mathrm{H}$ NMR: $\delta=$ $6.66(1 \mathrm{H}, \mathrm{s}$, aromatic $\mathrm{CH}), 4.38(4 \mathrm{H}, \mathrm{dd}, J=8$ and $8 \mathrm{~Hz}$, $\left.\mathrm{OCH}_{2}\right), 3.12(1 \mathrm{H}$, sept, $J=7 \mathrm{~Hz}$, isopropyl $\mathrm{CH}), 2.47$ $\left(3 \mathrm{H}, \mathrm{s}\right.$, aromatic $\left.\mathrm{CH}_{3}\right), 1.42\left(6 \mathrm{H}, \mathrm{t}, J=7 \mathrm{~Hz}, \mathrm{CH}_{3}\right), 1.31$ $\left(6 \mathrm{H}, \mathrm{d}, J=7 \mathrm{~Hz}\right.$, isopropyl $\left.\mathrm{CH}_{3}\right) .{ }^{13} \mathrm{C}$ NMR: $\delta=175.68$, $169.97,164.52,106.91 / 106.83$ (ring carbons), 65.28/65.21 $\left(\mathrm{OCH}_{2}\right), 37.42(\mathrm{CH}), 24.07$ (isopropyl $\left.\mathrm{CH}_{3}\right), 21.40$ (methyl $\mathrm{CH}_{3}$ ), 15.78/15.67 (ethoxy $\mathrm{CH}_{3}$ ). ${ }^{31} \mathrm{P}$ NMR: $\delta=$ 59.5ócconsistentówitháq̣́reviousóvalueđ7]).đR:á $=$ ¿974, 2931, 2906, 2873, 1587s, 1562s, 1471, 1444, 1383, 1352, $1294,1161,1099,1024 \mathrm{~s}, 995,982,951,831$. The infrared dataóparallelsóearlieródataó[8].ôNoóevidenceớforớthiono-

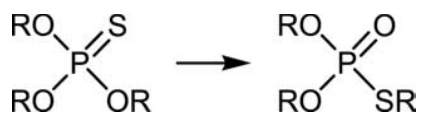

Figure 2. The thiono-thionolo rearrangement. thiolo rearrangement during storage was found using the spectroscopic techniques outlined above.

\section{O,O-Diethyl O-[2-Isopropyl-4-Methyl-6- Pyrimidinyl] Phosphate (Diazoxon)}

A solution of 2-isopropyl-4-methyl-6-pyrimidinol (3.53 g, $23.18 \mathrm{mmol})$ and triethylamine $(3.23 \mathrm{ml}, 23.18 \mathrm{mmol})$ in dichloromethane $(30 \mathrm{ml})$ was added dropwise to a stirred solution of diethyl chlorophosphate $(4 \mathrm{~g}, 23.18 \mathrm{mmol})$ in dichloromethane $(20 \mathrm{ml})$ at $0-5{ }^{\circ} \mathrm{C}$. After addition, the mixture was allowed to warm to room temperature. A catalytic amount of 4-dimethylaminopyridine was added. After $15 \mathrm{~min}$, the pale brown solution became turbid and a precipitate of triethylamine hydrochloride formed. The solution was heated under reflux for $2 \mathrm{~h}$. After cooling to room temperature, water $(20 \mathrm{ml})$ was added to dissolve the precipitate. The organic layer was separated, washed with $10 \% \mathrm{w} / \mathrm{w}$ sodium bicarbonate solution $(20 \mathrm{ml})$ and dried $\left(\mathrm{MgSO}_{4}\right)$. The drying agent was filtered off and the filtrate concentrated. Chromatography of the residue on silica gel, eluting with $4: 1$ hexane-acetone, gave the title compound as a colorless liquid $(4 \mathrm{~g}, 60 \%)$ of $>98 \%$ purity. $R_{f}$ in $2: 1$ hexaneacetone $=0.31\left(\mathrm{R}_{\mathrm{f}}\right.$ of starting pyrimidinol $\left.=0.08\right) .{ }^{1} \mathrm{H}$ NMR: $\delta=6.73(1 \mathrm{H}, \mathrm{s}$, aromatic $\mathrm{CH}), 4.34(4 \mathrm{H}, \mathrm{dd}, J=7$ and $\left.7 \mathrm{~Hz}, \mathrm{OCH}_{2}\right), 3.12(1 \mathrm{H}$, sept, $J=7 \mathrm{~Hz}$, isopropyl $\mathrm{CH})$, $2.49\left(3 \mathrm{H}\right.$, s, aromatic $\left.\mathrm{CH}_{3}\right), 1.4\left(6 \mathrm{H}, \mathrm{t}, J=7 \mathrm{~Hz}, \mathrm{CH}_{3}\right), 1.32$ $\left(6 \mathrm{H}, \mathrm{d}, J=7 \mathrm{~Hz}\right.$, isopropyl $\left.\mathrm{CH}_{3}\right) .{ }^{13} \mathrm{C}$ NMR: $\delta=176.24$, $170.63,164.8,106.5$ (ring carbons), $65.27\left(\mathrm{OCH}_{2}\right), 37.64$ (CH), 24.45 (isopropyl $\mathrm{CH}_{3}$ ), 21.78 (methyl $\mathrm{CH}_{3}$ ), 16.25 (ethoxy $\left.\mathrm{CH}_{3}\right) .{ }^{31} \mathrm{P}$ NMR: $\delta=-9.0$. IR(film): $\nu=2974$, 2931, 2873, 1589s, 1562s, 1446, 1383, 1354, 1290, 1165, $1028 \mathrm{~s}, 997,985,948,867,835 \mathrm{~s}$.

\section{Mass Spectrometry}

The mass spectrometric techniques and experimental conditions used in the present work have been describedônádetailáelsewheređ2]đutônáhisóworkónlyá̛he EsquirẽLC, Bruker Daltonics, GmbH (Bremen, Germany) was used. All ions were isolated before fragmentation, thus removing ambiguity in the precursor-fragment ion relationships.

\section{Electronic Structure Calculations}

The geometries of the pyrimidinol systems were fully optimized using the DFT approach with B3LYP pa- 


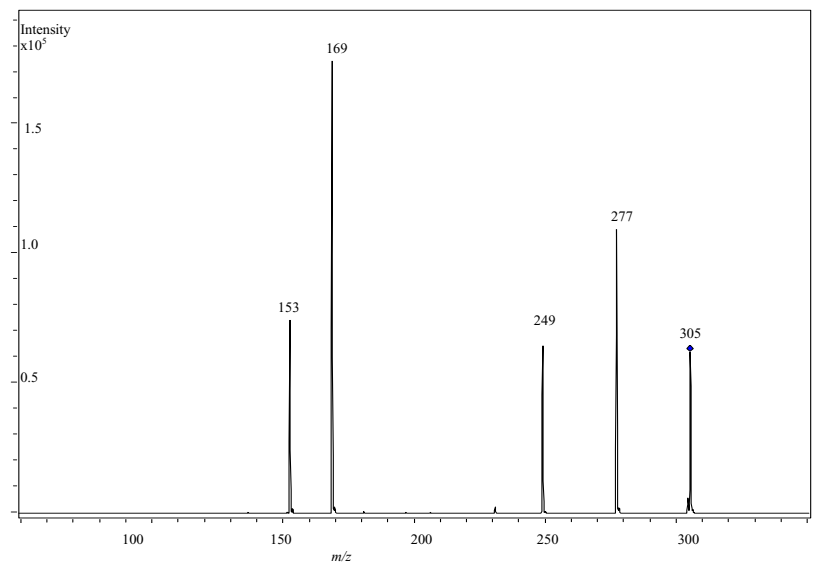

Figure 3. Fragmentation of protonated Diazinon, $\mathbf{I H}^{+}(m / z 305)$.

rameterizationđ9].óAđ̛ripleóralenceóplusádiffusionánd polarization functions basis set, 6-311 $+\mathrm{G}(2 \mathrm{~d}, 2 \mathrm{p})$, was chosen for calculations. Energies were corrected by the zero-point vibrational contribution. All calculations were done by using the Gaussian 03 package ofóprogramsớ[10].

\section{Results}

\section{Diazinon I}

Isolation and fragmentation of protonated Diazinon, $\mathrm{IH}^{+}$, produced four ions with $\mathrm{m} / \mathrm{z}$ values of 277,249 , 169,óandó153ó(Figureó3).óTheseóionsówereóisolatedóand fragmented, as were their fragment ions, and the results areósummarizedônófigureót.

The ions with $\mathrm{m} / \mathrm{z} 277$ and 249 are formed by sequential loss of ethene from the ethoxy groups as expectedó[1].óTheóionówithóm/z 153aóisóattributedóto protonated pyrimidinol, $\mathrm{IIIH}^{+}$, and that with $\mathrm{m} / z$ 169a

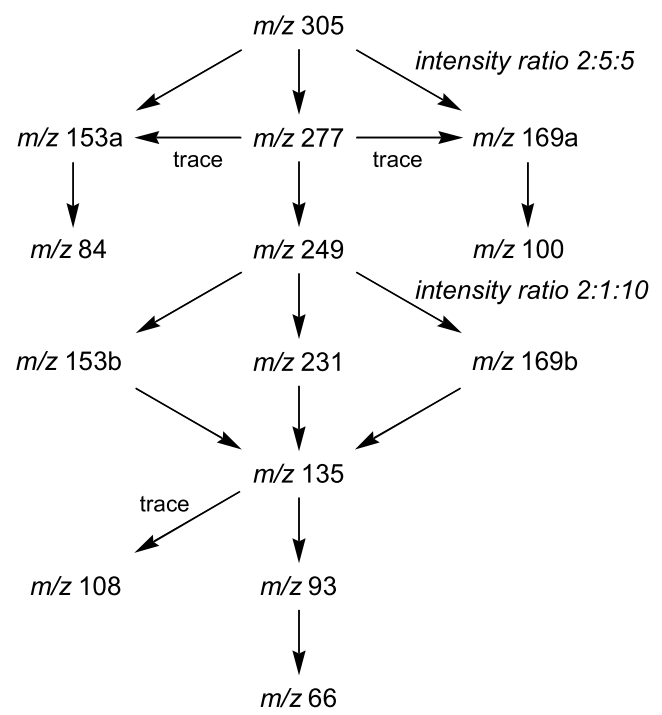

Figure 4. Fragmentation of protonated Diazinon, $\mathrm{IH}^{+}$and its product ions. to the corresponding protonated pyrimidinethiol, presumably formed by thiono-thiolo rearrangement of $\mathrm{IH}^{+}$. The designator a in $\mathrm{m} / \mathrm{z} 153 \mathrm{a}$ and 169 a distinguishes these ions from tautomer ions produced by fragmentation of $\mathrm{m} / \mathrm{z} 249$. The ions with $\mathrm{m} / \mathrm{z} 153$ and 169 isolated after fragmentation of protonated Diazinon are not pure $m / z$ 153a and 169a, but contain small amounts of $\mathrm{m} / \mathrm{z} 153 \mathrm{~b}$ and $169 \mathrm{~b}$. It is not immediately apparent whether the ions with $m / z 153 \mathrm{~b}$ and $169 \mathrm{~b}$ result solely from fragmentation of $m / z 249$ or also from fragmentation of $\mathrm{m} / \mathrm{z}$ 305. The ions $\mathrm{m} / \mathrm{z}$ 153a and 169a are distinguished from the isomeric ions $\mathrm{m} / \mathrm{z} 153 \mathrm{~b}$ and $169 \mathrm{~b}$ by their characteristic fragmentations, the ions with the designator a losing $69 \mathrm{Da}$ attributed to isobutyronitrile and those with the designator $b$ losing either $\mathrm{H}_{2} \mathrm{O}$ or $\mathrm{H}_{2} \mathrm{~S}$. Fragmentation of $\mathrm{m} / \mathrm{z} 277$ gives only traces of $\mathrm{m} / \mathrm{z}$ $153 a$ and $169 a$, the majority of the ion fragmenting to $\mathrm{m} / \mathrm{z} 249$ and its fragment ions. No $\mathrm{m} / \mathrm{z} 153 \mathrm{a}$ and 169a are produced on fragmentation of $\mathrm{m} / \mathrm{z} 249$. The results obtained when using $\mathrm{D}_{2}$ OóareóshownónớFigureớc.

The fragmentation of $\mathrm{m} / \mathrm{z} 250$ gives the surprising result that only $\mathrm{HDO}$ and not $\mathrm{H}_{2} \mathrm{O}$ is lost whereas the product ions from the alternative fragmentation routes show a partial retention of the deuteron.

\section{Diazoxon II}

The isolation and fragmentation of protonated Diazoxon, $\mathrm{IIH}^{+}$, and its product ions are very similar to that of protonated Diazinon except that, of course, the sulphur-containing ions are absent with the corresponding oxygen analogs appearing in their place. They areósummarizedônớFigureó́6.

Unlike the product ion formed from elimination of ethene from $\mathrm{IH}^{+}$, the analogous ion from protonated Diazoxon, $\mathrm{IIH}^{+}, m / z 261$, loses ethene to give $m / z 233$ but also $m / z$ 153a. Similarly, fragmentation of $m / z 233$ gives traces of $\mathrm{m} / \mathrm{z} 153 \mathrm{a}$ in addition to the expected $\mathrm{m} / \mathrm{z}$ $153 \mathrm{~b}$ and 215.

\section{2-Isopropyl-4-Methyl-6-Pyrimidinol III}

Fragmentation of $\mathrm{IIIH}^{+}, \mathrm{m} / \mathrm{z}$ 153, obtained from a pure sample of III gave a 20:1 ratio of the ions with $\mathrm{m} / \mathrm{z} 84$

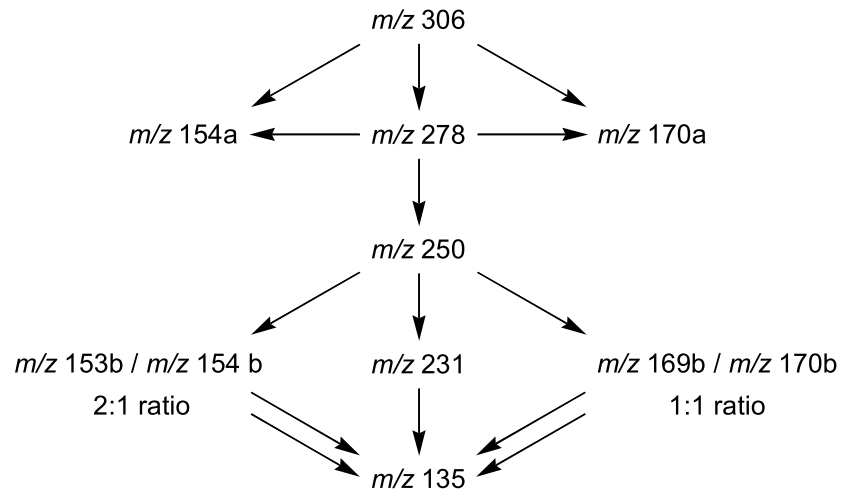

Figure 5. Fragmentation of $\mathrm{ID}^{+}$and its product ions. 


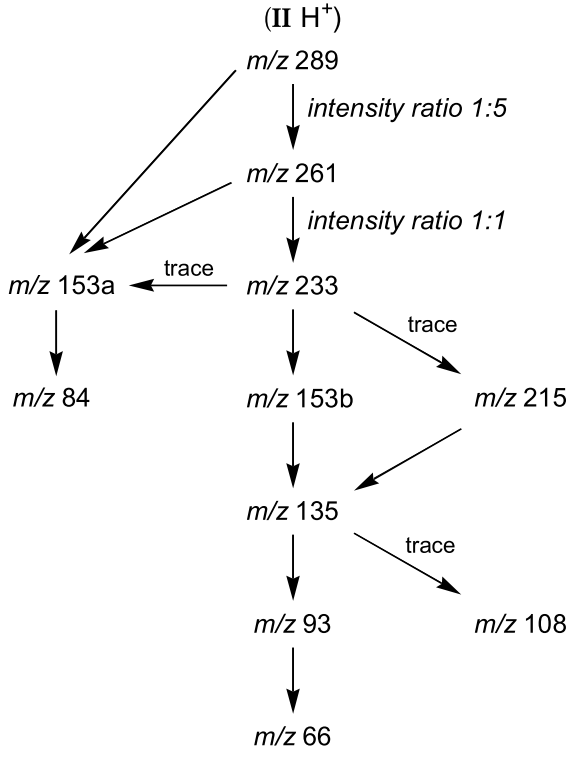

Figure 6. Fragmentation of protonated Diazoxon and its product ions.

and 135 which suggests that $\mathrm{IIIH}^{+}$is a $20: 1$ mixture of $\mathrm{m} / \mathrm{z} 153 \mathrm{a}$ and $153 \mathrm{~b}$.

\section{Electronic Structure Calculations}

The results of the present calculations together with somećearlierónesóareógivenónôTableól.

\section{Discussion}

\section{Sites of Protonation}

It is appropriate to consider the structure of protonated Diazinon before discussing its fragmentation. Heterocycles with hydroxyl or thiol groups positioned $\alpha$ or $\gamma$ to a ring nitrogen can exist as a mixture of tautomers [11].óTheópositionóofóequilibriumódependsóuponóthe compound, the medium, and whether it is in the gas phase or in solution. The equilibrium position for 4-hydroxypyrimidineó́Figureơ)đhasđbeenóstudiedônớhe gas phase and the keto and enol forms are almost equallyóstableó[12].óUnfortunatelyóketo-enolótautomer-

Table 1. Calculated proton affinities of the basic groups in Diazinon

\begin{tabular}{lcc}
\hline Group or compound & $\begin{array}{c}\text { Proton affinity } \\
\left(\mathrm{kJ} \mathrm{mol}^{-1}\right)\end{array}$ & Reference \\
\hline \hline $\mathrm{P}=\mathrm{S}$ & 880 & 3 \\
$\mathrm{P}-\mathrm{SR}$ & 820 & 3 \\
$\mathrm{P}=\mathrm{O}$ & 890 & 3 \\
$\mathrm{P}-\mathrm{OR}$ & 780 & 3 \\
2-Isopropyl-4-methyl- & $945(N-1)$ & this work \\
6-pyrimidinol & $956(N-3)$ enol & \\
& $957(N-3)$ keto $^{\mathrm{a}}$ & \\
\hline
\end{tabular}

aThe neutral keto tautomer is $8 \mathrm{~kJ} \mathrm{~mol}^{-1}$ more stable than the enol tautomer.<smiles></smiles>

Figure 7. Tautomers of 4-hydroxypyrimidine.

isms of protonated species relevant to this study do not appear to have been studied in the gas phase.

In addition to keto-enol tautomerism of the protonated pyrimidine, proton tautomerism between the two nitrogen atoms is possible. In the gas phase movement of the proton between the nitrogen atoms will presumably be prevented by a high energy barrier because of the rigidity of the ring, in contrast to systems with peptideđbondsówheređ̛́heóprotonôsómobileđ̛13].óConsideration of proton affinities of the heteroatoms in Diazinon suggests that three sites are important: the thiono sulphur atom and the two pyrimidine nitrogen atoms (Tableól).

Placement of the proton on the thiono sulphur atom is unlikely to lead to the fragmentations observed without its migration presumably to $\mathrm{N}-1$ of the pyrimidine ring. Thus only two placements of the proton on Diazinon need to be considered. These are as shown in Figureó8;óoxoniumóformsóareódrawnóbutótheópositive charge could equally reside on $\mathrm{NH}$. The structures are designated $m / z 305_{(\mathrm{P}=\mathrm{S} 1 \mathrm{H})}$ and $\mathrm{m} / \mathrm{z} 305_{(\mathrm{P}=\mathrm{S} 3 \mathrm{H})}$, the $\mathrm{P}=\mathrm{S}$ indicating the thiono structure (and, more importantly, the $\mathrm{P}-\mathrm{O}$-pyrimidine bonding) and the number prefixing $\mathrm{H}$ denoting the nitrogen bearing the proton.

At this juncture it is necessary to consider the structures of $\mathrm{m} / \mathrm{z} 153 \mathrm{a}$ and $153 \mathrm{~b}$ (and by implication, the structures of $\mathrm{m} / \mathrm{z} 169 \mathrm{a}$ and $169 \mathrm{~b}$ for, as mentioned earlier, they fragment along parallel pathways). The simplest explanation for the difference between these ions is that they are protomers of protonated pyrimidinol, $\mathrm{IIIH}^{+}$. Movement of the proton between the ring nitrogen atoms is unlikely to occur in the gas phase, as suggested earlier, and was confirmed by stable isolations of $\mathrm{m} / \mathrm{z} 153 \mathrm{a}$ and $\mathrm{m} / \mathrm{z} 153 \mathrm{~b}$. That these ions are protomers and not structural isomers is supported by the fragmentation of $\mathrm{m} / \mathrm{z} 153$ from a pure sample of the pyrimidinol III. But which protomer is which? This can be deduced from the observation that $\mathrm{m} / \mathrm{z}$ 153b loses $\mathrm{H}_{2} \mathrm{O}$ on fragmentation. This is most likely to occur in the protomer with the proton on the nitrogen atom adjacent to the hydroxy group. The structures appear in

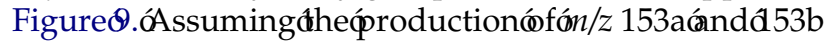


Figure 8. Protomers of protonated Diazinon. 


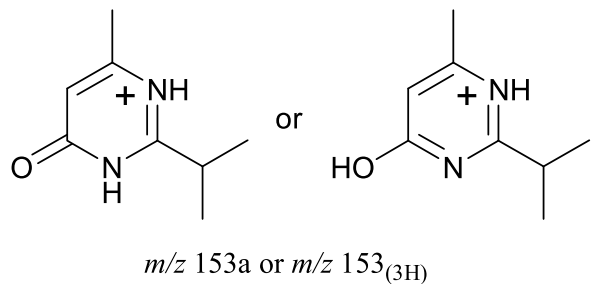<smiles>Cc1cc(O)[nH+]c(C(C)C)n1</smiles>

$m / z 153$ b or $m / z 153_{(1 \mathrm{H})}$

Figure 9. Protomers and tautomers of the pyrimidinol side chain.

in the gas phase occurs at approximately the temperature of the drying gas $\left(300^{\circ} \mathrm{C}\right)$, their observed ratio of 20:1 deduced from the fragmentation of $m / z 153$, is in good agreement with that calculated from the proton affinitiesógivenônôTableól.

The sulphur analogs $m / z$ 169a and $169 \mathrm{~b}$ will have corresponding structures designated $m / z 169_{(3 \mathrm{H})}$ and $169_{(1 \mathrm{H})}$.

\section{Thiono-Thiolo Rearrangements}

An intramolecular thiono-thiolo rearrangement of protonated simple organophosphorus esters was not observed in the gas phase, and electronic structure calcu-

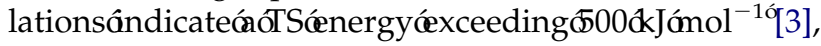
much greater than the TS energies for the rearrangements and fragmentations normally observed with organophosphateóestersó[3,ó14].óThus,ótheófacileóthionothiolo rearrangement observed with $\mathrm{IH}^{+}$can be attributed to the strong positive charge on the C- 6 of the pyrimidineóringóinótheóstructuresóshownóinóFigureó8. That both protomers rearrange confirms that isomerization results from direct nucleophilic attack of the sulphur on C-6 rather than via some more complex TS involving the nitrogens (with or without a proton) of the pyrimidine ring. Attack at the 5-position, although perhaps favored for steric reasons, is not possible on electronic grounds. Rearrangement to the 6-position is supported by common pathways of fragmentation of $m / z 305_{(\mathrm{P}=\mathrm{S})}$ and $305_{(\mathrm{P}=\mathrm{O})}$.

Fragmentation of $m / z 305_{(\mathrm{P}=\mathrm{S} 3 \mathrm{H})}$ and $\mathrm{m} / \mathrm{z} 305_{(\mathrm{P}=\mathrm{O} 3 \mathrm{H})}$

These ions fragment to give $m / z 153_{(3 \mathrm{H})}$ and $169_{(3 \mathrm{H})}$ as the respective sole ionic products. Their stoichiometry requires a hydrogen from one of the ethyl groups to be transferred to the protonated pyrimidino moiety. Thus, concerted elimination of ethene and a metaphosphorothionate or metaphosphate is the most likely mechanismóandâsâlllustratedânớFigureól0,átheócurvedóarrows referring to the eliminations and not to the thiono-thiolo rearrangement.

Fragmentation of $\mathrm{m} / \mathrm{z} 305_{(\mathrm{P}=\mathrm{S} 1 \mathrm{H})}$ and $\mathrm{m} / \mathrm{z} 305_{(\mathrm{P}=\mathrm{O} 1 \mathrm{H})}$

These ions lose ethene to give $\left.m / z \quad 277_{(\mathrm{P}=\mathrm{S}} \quad 1 \mathrm{H}\right)$ and $m / z 277_{(\mathrm{P}=\mathrm{O} 1 \mathrm{H})}$ which, in turn, also lose ethene to give $m / z 249_{(\mathrm{P}=\mathrm{S} 1 \mathrm{H})}$ and $m / z 249_{(\mathrm{P}=\mathrm{O} 1 \mathrm{H})}$, respectively. While loss of ethene might be expected to follow the

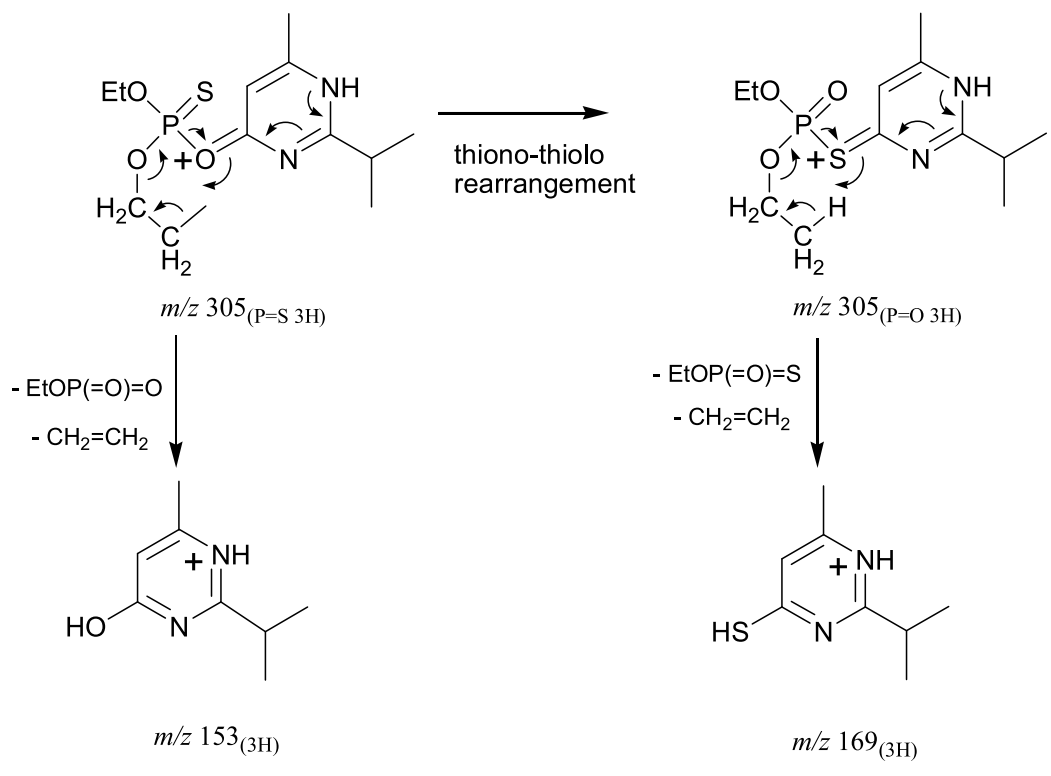

Figure 10. Fragmentation of $m / z 305_{(3 \mathrm{H})}$. 


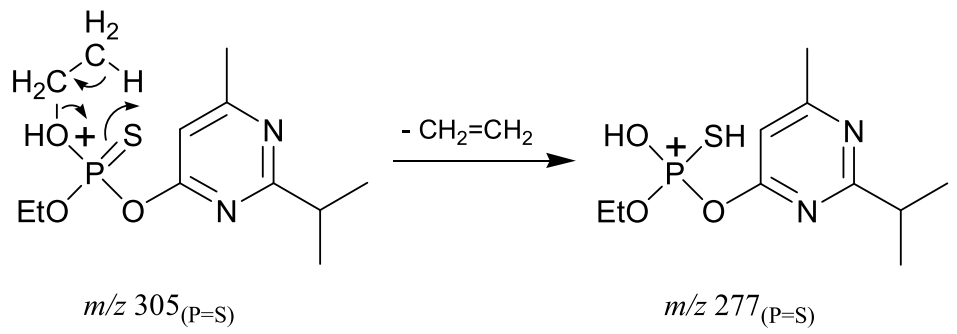

Figure 11. Fragmentation of $m / z 305_{(\mathrm{P}=\mathrm{S})}$.

mechanism illustrated for $\mathrm{m} / \mathrm{z} 305_{(\mathrm{P}=\mathrm{S})}$ [when no subscript is attached to a $\mathrm{m} / \mathrm{z}$ value, no distinction is made between the various possible structures, i.e., whether the ion has the $\mathrm{P}=\mathrm{S}$ of $\mathrm{P}=\mathrm{O}$ form or the location of the proton on the pyrimidine ring cannot be discerned] in Figureó11,óprotonationóofóanóethoxyóoxygenóatomóis unlikely, given the greater proton affinity of the pyrimidine nitrogen atoms. However, when using $\mathrm{D}_{2} \mathrm{O}$, in the final product ion following the sequential ethene elimination, $m / z 250$, the deuterium remains on the pyrimidine ring (scrambling with hydroxyl hydrogens on the phosphorus moiety does not occur as if it did both $\mathrm{H}_{2} \mathrm{O}$ and HDO would be expected to be eliminated - see later). The ${ }_{3 \mathrm{H}}$ tautomers are not involved as $\mathrm{m} / \mathrm{z} 153_{(1 \mathrm{H})}$ and $169_{(1 \mathrm{H})}$ and not their $3 \mathrm{H}$ tautomers are formed. When the proton (or deuteron) is on $N-1$, it can interact directly with the phosphorus moiety in two ways depending on the conformation. Two conformers, designatedóaćandðb,ćareóshownânớigureól 2.

Since the proton affinity of $\mathrm{N}-1$ is significantly greater than that of the thiono sulphur atom in $\left.\mathrm{m} / \mathrm{z} 305_{(\mathrm{P}=\mathrm{S}} 1 \mathrm{H}\right)$, the proton will be attached to $\mathrm{N}-1$. Conformer a is unreactive to fragmentation, but Conformer $\mathrm{b}$ can fragment via the mechanism illustrated in Figureó13ótoóproduceóetheneóandóm/z 277 $7_{(\mathrm{P}=\mathrm{S} 1 \mathrm{H})}$ [the designator $\mathrm{P}=\mathrm{S}$ is still used as the $\mathrm{P}-\mathrm{O}$-pyrimidine bond is intact] which can fragment similarly.

The ions $m / z 305_{(\mathrm{P}=\mathrm{O} 1 \mathrm{H})}$ and $277_{(\mathrm{P}=\mathrm{O} 1 \mathrm{H})}$ can fragment similarly. In addition to the ions with $\mathrm{m} / \mathrm{z} 153_{(1 \mathrm{H})}$ and $169_{(1 \mathrm{H})}$ being formed on fragmentation of $m / z 249_{(1 \mathrm{H})}$, an ion with $\mathrm{m} / \mathrm{z} 231$ formed by loss of water is observed. Loss of $\mathrm{H}_{2} \mathrm{~S}$ to give an ion with $\mathrm{m} / \mathrm{z} 215$ is not observed.
On using $\mathrm{D}_{2} \mathrm{O}$ the isotopomeric ions $\mathrm{m} / \mathrm{z} 250_{(1 \mathrm{D})}$ are isolated which on fragmentation gives $\mathrm{m} / \mathrm{z} 169_{(1 \mathrm{H})}$, $170_{(1 \mathrm{D})}$, ó153 $3_{(1 \mathrm{H})}, \mathrm{o} 154_{(1 \mathrm{D})}$, óandó231ó(seeóFigureó14).óThe ratio of the isotopomers is unusual with that ratio $\mathrm{m} / \mathrm{z}$ $169_{(1 \mathrm{H})}: \mathrm{m} / \mathrm{z} 170_{(1 \mathrm{D})}$ being ca. $1: 1$, that of $\mathrm{m} / \mathrm{z} 153_{(1 \mathrm{H})}: \mathrm{m} / \mathrm{z}$ $154_{(1 \mathrm{D})}$ being ca. 2:1 and no deuterated isotopomer of $\mathrm{m} / \mathrm{z} 231$. (It is interesting to note that when fragmenting the deuterated isotopomer $\mathrm{m} / \mathrm{z} 234$ from the oxygen analog of Diazinon the ratio $\mathrm{m} / \mathrm{z} 153_{(1 \mathrm{H})}: \mathrm{m} / \mathrm{z} 154_{(1 \mathrm{D})}$ is also ca. 2:1 and again only HDO is lost). It was expected, and indeed partially confirmed by these results, that a proton/deuteron in the 1 position of the pyrimidine ring can exchange with a proton/deuteron on the phosphorus moiety. It is difficult to rationalize the isotopomer ratios in the product ions, and in particular the sole loss of $\mathrm{HDO}$ rather than $\mathrm{H}_{2} \mathrm{O}$, unless there is an energy barrier to $\mathrm{H} / \mathrm{D}$ exchange and fragmentation.

This is perhaps not unreasonable as exchange can be envisagedớtoânvolveớtheớransformationóshownónớigureó15,ówithótheóright-handóstructureórepresentingóa transition state in $\mathrm{H} / \mathrm{D}$ scrambling. Before excitation, the deuteron will be sequestered on the ring nitrogen $\mathrm{N}-1$. It is suggested that elimination of $\mathrm{H}_{2} \mathrm{O}$, or $\mathrm{HDO}$ when using $\mathrm{D}_{2} \mathrm{O}$, occurs from the left-hand structure before $\mathrm{H} / \mathrm{D}$ exchange takes place. Also, fragmentation to produce $\mathrm{m} / z 169_{(1 \mathrm{H})}$ only occurs via the high-energy right-hand structure. During this fragmentation, a proton or deuteron will have to return to the ring nitrogen, but this will have to be a concerted process (if reversion to the left-hand structure took place, some $\mathrm{H}_{2} \mathrm{O}$ would be expected to be eliminated, and this was not observed). The different isotope ratios between $\mathrm{m} / \mathrm{z}$<smiles></smiles>

$m / z 305_{(\mathrm{P}=\mathrm{S} 1 \mathrm{H})}$

Conformer a

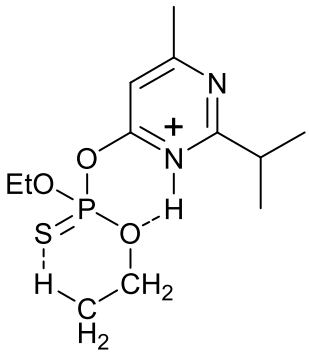

$m / z 305_{(\mathrm{P}=\mathrm{S} 1 \mathrm{H})}$

Conformer $\mathrm{b}$

Figure 12. Conformers of the ${ }_{(1 \mathrm{H})}$ protomer of $\mathrm{IH}^{+}$.

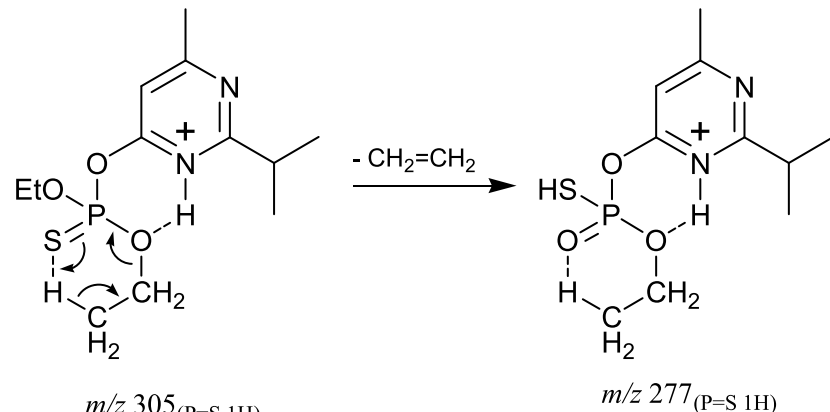

Conformer b

Figure 13. Fragmentation of $m / z 305_{(\mathrm{P}=\mathrm{S} 1 \mathrm{H})}$, Conformer $\mathrm{b}$. 


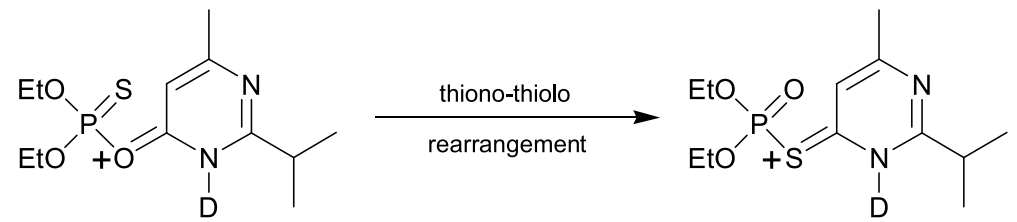

$m / z 306_{(\mathrm{P}=\mathrm{S} 1 \mathrm{D})}$

$m / z 306_{(\mathrm{P}=\mathrm{O} 1 \mathrm{D})}$
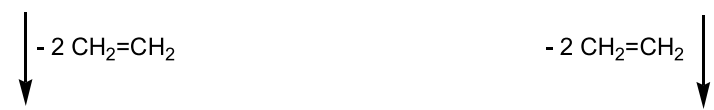<smiles></smiles>

$m / z 250_{(\mathrm{P}=\mathrm{S} 1 \mathrm{D})}$
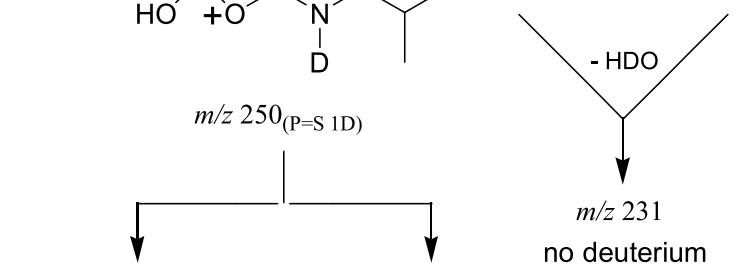<smiles>[2H]n1c(C(C)C)nc(C)cc1=[SH]P(=O)(O)O</smiles>

$\left.m / z 250_{(\mathrm{P}=\mathrm{O}} 1 \mathrm{D}\right)$

$m / z 231$

no deuterium<smiles>Cc1cc(O)[nH+]c(C(C)C)n1</smiles><smiles>[2H][n+]1c(O)cc(C)nc1C(C)C</smiles>

$m / z 153_{(1 \mathrm{H})}$

$m / z 154_{(1 \mathrm{D})}$

2:1 ratio

$1: 1$ ratio

Figure 14. Fragmentations of $m / z 306_{(1 \mathrm{D})}$ and $m / z 250_{(1 \mathrm{D})}$.

$153_{(1 \mathrm{H})} / 154_{(1 \mathrm{D})}$ and $m / z 169_{(1 \mathrm{H})} / 170_{(1 \mathrm{D})}$ are attributed to kinetic isotope effects.

That there is no discernable loss of $\mathrm{H}_{2} \mathrm{~S}$ from $\mathrm{m} / \mathrm{z}$ $249_{(1 \mathrm{H})}$ can be rationalized by $\mathrm{m} / z \quad 249_{(1 \mathrm{H})}$ being a mixture of $m / z 249_{(\mathrm{P}=\mathrm{S} 1 \mathrm{H})}$ and $m / z 249_{(\mathrm{P}=\mathrm{O} 1 \mathrm{H})}$ with the latter dominating as indicated by the relative intensities of product ions $m / z 153_{(1 \mathrm{H})}$ and $m / z 169_{(1 \mathrm{H})}$. As $m / z 231$ only loses $\mathrm{PO}_{2} \mathrm{SH}$ as the neutral fragment, it is not possible to say which subscript ${ }_{(\mathrm{P}=\mathrm{S} 1 \mathrm{H})}$ or ${ }_{(\mathrm{P}=\mathrm{O} 1 \mathrm{H})}$ or both is appropriate. Isolation and fragmentation of both $\mathrm{m} / \mathrm{z}$ $154_{(1 \mathrm{D})}$ and $m / z 170_{(1 \mathrm{D})}$ gives $m / z 135$. On isolation, $m / z$ 135 can be fragmented further with sequential loss of 42 $\mathrm{Da}\left(\mathrm{C}_{3} \mathrm{H}_{6}\right)$ and $27 \mathrm{Da}(\mathrm{HCN})$ giving ions $\mathrm{m} / \mathrm{z} 93$ and $\mathrm{m} / \mathrm{z}$
66. It also loses $\mathrm{HCN}$ to give a trace of $m / z 108$. The fragmentationsǿfớn/z 305árésummarizedônđ̛igureôl 6.

\section{Previous Studies on Diazinon}

As mentioned in the introduction, there have been two studiesóonótheođESI-MS-MSóofỏiazinonđ[5,ób]đbutóusing tandem-in-space rather than the present tandem-intimeóinstrumentation.óTheóearlieróstudyó[5]ófoundóthe ions $m / z 169$ and 153 to be the dominant fragment ions from $\mathrm{IH}^{+}$. Ions attributed to sequential loss of ethene were present only in trace amounts. This situation is the converse from the present study where loss of ethene is

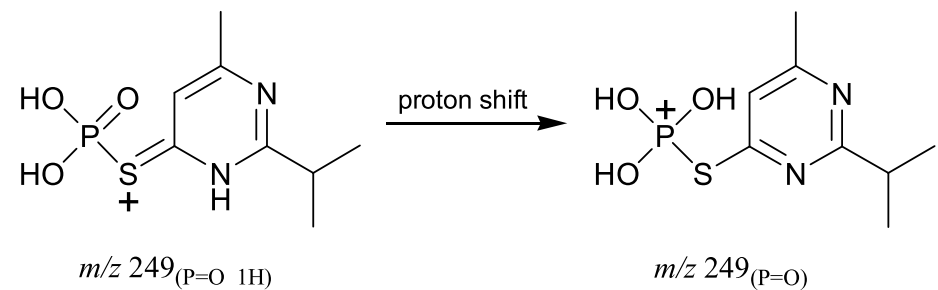

Figure 15. Proton shift from the pyrimidinol side chain to the phosphorus moiety prior to the elimination of water. 
<smiles>CCOP(=S)(OCC)O[P@](=S)(OCC)OC(C)=S=c1cc(C)nc(C(C)C)[nH]1</smiles>

$m / z 305_{(\mathrm{P}=\mathrm{S} 1 \mathrm{H})}$<smiles>C=C[13C](C)(C)C</smiles><smiles>CCOP(O)(=S)[O+]=c1cc(C)nc(C(C)C)[nH]1</smiles>

$m / z 277_{(\mathrm{P}=\mathrm{S} 1 \mathrm{H})}$<smiles>C=C[13C](C)C</smiles><smiles></smiles>

$m / z 249_{(\mathrm{P}=\mathrm{S} 1 \mathrm{H})}$<smiles>Cc1cc(O)[nH+]c(C(C)C)n1</smiles>

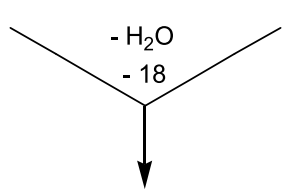

$m / z 231_{(1 \mathrm{H})}$ $m / z 305_{(\mathrm{P}=\mathrm{O} 1 \mathrm{H})}$

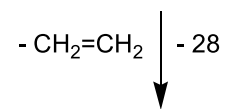<smiles>CCOP(=O)(O)[Se]=c1cc(C)nc(C(C)C)[nH]1</smiles>

$$
m / z 277_{(\mathrm{P}=\mathrm{O} 1 \mathrm{H})}
$$

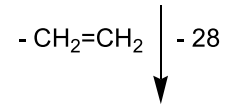<smiles>Cc1cc(=S(=O)(O)O)[nH]c(C(C)C)n1</smiles>

$m / z 249_{(\mathrm{P}=\mathrm{O} 1 \mathrm{H})}$<smiles>C[13C](C)[13C](C)[18OH]</smiles><smiles></smiles>

$m / z 169_{(1 \mathrm{H})}$



trace $m / z 108$

$m / z 93$

- HCN

$\mathrm{m} / \mathrm{z} 66$

Figure 16. Fragmentations of $\mathrm{m} / \mathrm{z} 305$ and its product ions.

the dominant fragmentation pathway. The authors of the early study also reported an ion with $\mathrm{m} / \mathrm{z} 125$ which was not observed in the present study. While their attribution of $\mathrm{m} / \mathrm{z} 153$ to $\mathrm{IIIH}^{+}$agrees with our results, their assignment of $m / z 169$ to $(\mathrm{EtO})_{2} \mathrm{P}(\mathrm{O})(\mathrm{S})^{+}$does not; such an assignment ignores the possibility of thiono- thiolo rearrangement and requires a most unlikely fragmentation.ôTheómoreớrecentóstudyớ6] ódwhichódoes not refer to the earlier one) described dominant fragment ions with $\mathrm{m} / \mathrm{z} 169$ and $\mathrm{m} / \mathrm{z} 153$, but only traces of ions from sequential loss of ethene, and no ion with $\mathrm{m} / \mathrm{z}$ 125. The authors of this study attributed ion $\mathrm{m} / \mathrm{z} 169$ to 
the sulphur analog of $\mathrm{IIIH}^{+}$resulting from a thionothiolo rearrangement, although they were undecided as to where and how this took place. Neither of the two reported studies provided more detail on the fragmentations. In the absence of a more detailed comparison, the differences between the previous studies and the present one are tentatively ascribed to the differences in energies and time scales of the fragmentations, 50 and $12 / 25 \mathrm{eV}$ for the two earlier studies on $\mu$ s time scales and $<3 \mathrm{eV}$ and $30 \mathrm{~ms}$ for the present.

\section{Conclusions}

This study illustrates how the use of electrospray ionization ion trap mass spectrometry can reveal detailed structural information on the fragmentations and reactions of organophosphate esters. Study of the pesticide Diazinon under such conditions has revealed the importance of thiono-thiolo rearrangements and tautomeric equilibria in the gas phase; both phenomena are poorly understood at present. Future studies will examine the thiono-thiolo rearrangements of structurally simpler analogs of Diazinon. The observed complexity of the gas-phase ion processes indicates that considerable care and understanding is necessary if this approach is to be used in analyzing environmental samples.

\section{Acknowledgments}

The authors thank the Leverhulme Trust for financial support to JDB and the EC Reactive Intermediates RT Network for financial support of this project.

\section{References}

1. Bell, A. J.; Despeyroux, D.; Murrell, J.; Watts, P. Fragmentations and reactions of organophosphate ions produced by electrospray ionization. Int. J. Mass Spec. Ion Processes 1997, 165/166, 533.

2. Barr, J. D.; Bell, A. J.; Konn, D.; Murrell, J.; Timperley, C. M.; Waters, M. J.; Watts, P. Fragmentations and reactions of three isotopically labeled dimethyl methylphosphonate ions produced by electrospray ionization in an ion trap mass spectrometer. Phys. Chem. Chem. Phys. 2002, 4, 2200.

3. Barr, J. D.; Bell, A. J.; Ferrante, F.; LaManna, G.; Mundy, J. L.; Timperley, C. M.; Waters, M. J.; Watts, P. Fragmentations and reactions of some isotopically labeled dimethyl methylphosphono and trimethyl phosphoro thiolates and thionates studied by electrospary ionization ion trap mass spectrometry, unpublished.
4. Bell, A. J.; Murrell, J.; Timperley, C. M.; Watts, P. Fragmentations and reactions of two isomeric O-alkyl S-(2-dialkylamino)ethyl methylphosphonothiolates studied by electrospray ionization/ion trap mass spectrometry. J. Am. Soc. Mass Spectrom. 2001, 12, 902.

5. Banoub, J.; Gentil, E.; Kiceniuk, J. Analysis of organophosphorus pesticide residues by low energy tandem mass spectrometry using electrospray ionization. Int. J. Environ. Anal. Chem. 1995, 61, 143.

6. Kouloumbous, V. N.; Tsipi, D. F.; Hiskia, A. E.; Nikolic, D.; van Breeman, R. B. Identification of photocatalytic degradation products in $\mathrm{TiO}_{2}$ aqueous suspensions using GC/MS/MS and LC/MS with quadrupole time-of-flight mass spectrometry. J. Am. Chem. Soc. Mass Spectrom. 2003, 14, 803.

7. Ross, R. T.; Biros, F. J. Correlations between ${ }^{31} \mathrm{P}$ NMR chemical shifts and structures of some organophosphorus residues. Anal. Chim. Acta 1970, 52, 139.

8. Pardue, J. R.; Hansen, E. A.; Barron, R. P.; Chen, J.-Y. T. Diazinon residues on field sprayed kale. J. Agric. Food Chem. 1970, 18, 405.

9. Becke, A. D. Density-functional exchange-energy approximations with asymptotic behavior. Phys. Rev. A 1988, 38, 3098.

10. Frisch, M. J.; Trucks, G. W.; Schlegel, H. B.; Scuseria, G. E.; Robb, M. A.; Cheeseman, J. R.; Montgomery, J. A., Jr.; Vreven, T.; Kudin, K. N.; Burant, J. C.; Millam, J. M.; Iyengar, S. S.; Tomasi, J.; Barone, V; Mennucci, B.; Cossi, M.; Scalmani, G.; Rega, N.; Petersson, G. A.; Nakatsuji, H.; Hada, M. M.; Ehara, M.; Toyota, K.; Fukuda, R.; Hasegawa, J.; Ishida, M.; Nakajima, T.; Honda, Y.; Kitao, O.; Nakai, H.; Klene, M.; Li, X.; Knox, J. E.; Hratchian, H. P.; Cross, J. B.; Adamo, C.; Jaramillo, J.; Gomperts, R.; Stratmann, R. E.; Yazyev, O.; Austin, A. J.; Cammi, R.; Pomelli, C.; Ochterski, J. W.; Ayala, P. Y.; Morokuma, K.; Voth, G. A.; Salvador, P.; Dannenberg, J. J.; Zakrzewski, V. G.; Dapprich, S.; Daniels, A. D.; Strain, M. C.; Farkas, O.; Malick, D. K.; Rabuck, A. D.; Raghavachari, K.; Foresman, J. B.; Ortiz, J. V.; Cui, Q.; Baboul, A. G.; Clifford, S.; Cioslowski, J.; Stefanov, B. B.; Liu, G.; Liashenko; A.; Piskorz, P.; Komaromi, I.; Martin, R. L.; Fox, D. J.; Keith, T.; Al-Laham, M. A.; Peng, C. Y.; Nanayakkara, A.; Challacombe, M.; Gill, P. M. W.; Johnson, B.; Chen, W.; Wong, M. W.; Gonzalez, C.; Pople, J. A. Gaussian 03, Revision B.04; Gaussian, Inc.: Pittsburgh, PA, 2003.

11. Newholme, G. R.; Paudler, W. W. Contemporary Heterocyclic Chemistry; Wiley: New York, 1982. Gilchrist, T. L. Heterocyclic Chemistry, 3rd. ed.; Prentice Hall: 1997, pp 32-35. Smith M. B. ; March, J.; March's Advanced Organic Chemistry, 5th ed.; Wiley: New York, 2001; pp 75-76.

12. Beak, P.; Fry, F. S., Jr.; Lee, J.; Steele, F. Equilibration studies. Protomeric equilibria of 2- and 4-hydroxypyridines, 2- and 4-hydroxypyrimidines, 2- and 4-mercaptopyridines and structurally related compounds in the gas phase. J. Am. Chem. Soc. 1976, 98, 71.

13. Harrison, A. G.; Yalcin, T. Proton mobility in protonated amino acids and peptides. Int. J. Mass Spectrom. Ion Processes 1997, 165/166, 339.

14. Bell, A. J.; Citra, A.; Dyke, J. M.; Ferrante, F.; Gagliardi, L.; Watts, P. An ab initio and DFT study of the fragmentation and isomerization of $\mathrm{MeP}(\mathrm{O})(\mathrm{OMe})^{+}$. Phys. Chem. Chem. Phys. 2004, 6, 1213. 